\title{
The Influence of Wastewater from Paper Mills on the Biological Process in the Municipal Wastewater Treatment Plant
}

\begin{abstract}
CARMEN TOCIU*, CRISTINA MARIA, ECATERINA MARCU, IRINA-ELENA CIOBOTARU
National Institute for Research and Development in Environmental Protection, 294 Splaiul Independentei, 060031, Bucharest

Wastewaters resulting from paper mills have high organic loading that in mostcases exceeds the maximum limits allowed for their discharge in the aquatic environment. In the context of concerns regarding the sustainable development of water resources, the identification of solutions for the optimal management of effluent treatment is a challenge of the modern society. This paper depicts the biological treatability of wastewaters resulting from the manufacturing of recycled paper and discusses their effect on the biological process after their admission in the municipal wastewater treatment plant. The Symons criterion and the Zahn-Wellens method were employed in order to study the biodegradability of organic substances as they are useful tools for prefiguring the behaviour of wastewaters during the secondary treatment step.
\end{abstract}

Keywords: biological treatment, recovered paper, wastewater

Paper mills are often located on the industrial platforms in urban agglomerations and have the opportunity to use the municipal wastewater treatment facilities, provided that the removal efficiencies of pollutants are comparable to that of the municipal wastewater [1].

The coagulation of non-settleable colloidal solids and the stabilization of organic matter from wastewaters are accomplished biologically using a variety of microorganisms (bacteria). After the bacterial metabolism, the substances and the nutrients from wastewaters are converted to cellular components, energy and non-toxic degradation product $\left(\mathrm{CO}_{2}, \mathrm{H}_{2} \mathrm{O}, \mathrm{CH}_{4}\right.$ and other), by physical and biochemical treatment processes. [2-4].

The biological treatability of wastewaters may be defined as the ability of organic matter to be degraded, correlated to the ability of biomass to decompose it during the process [5].

Symons criterion expresses the treatability of wastewaters by means of the $B O D_{5} / C O D(R)$ ratio. For $R=$ $0.5 \ldots 1.0$ wastewater has a good treatability and for $R=$ $0.1 \ldots 0.2$, wastewater is hardly treated biologically or it contains toxic substances. Between these values, respectively for $R=0.2 \ldots 0.5$, the bacterial population needs to be adjusted to the composition and concentration of the wastewater as itconcerns an average biological treatability [6-8].

Another method used for the analysis of the biological treatability is the Zahn-Wellens method. This method allows the determination of the degree of maximum biodegradation of water soluble organic compounds present in a certain concentration, under the action of aerobic microorganisms and during a testing period previously established [9].

This paper focuses on establishing the effect of the effluent resulting from a paper mill that uses paper wastes without deinking on the biological process from a municipal wastewater treatment plant.

Wastewater from paper industry are characterised by high flow rates and different loads of suspended matter, organic substances, nitrogen compounds and other contaminants specific to the additives used in the manufacturing process [10]. When such wastewaters with high organic content are insufficiently treated and discharged, their biological stabilisation may lead to the

*email: tociucarmen@yahoo.com; Phone: (+40)213052675 depletion of natural oxygen resources and to the development of septic conditions [11,12].

Water is an integral part of the national heritage. The protection, improvement and sustainable development of water resources are actions of national interest. The advanced state of pollution of numerous water bodies endangers their safe use and raises an issue of particular topicality worldwide, namely the protection of water resources quality [13].

\section{Experimental part}

The evaluation of biological treatability of wastewaters was accomplished by two methods, namely the determination of the Symons criterion and the ZahnWellens method. For this purpose, the following types of wastewater were sampled and analysed $[9,14,15]$ :

- wastewater discharged from paper manufacturing (EPM);

- the influent of the municipal wastewater treatment plant that does not contain the effluent from the paper mill (IWTP);

- a mixture (A) consisting of paper mill effluent (EPM) and sewage wastewater (IWTP) 1:30 (v:v) (according to the ratio between the water flows of each category of wastewater).

The Zahn-Wellens method is conducted usually for a time period of 28 days. The tested wastewater is the only source of carbon and energy for the microorganisms; the wastewater sample and the microorganisms are inserted into an inorganic synthetic medium.

Parallel with the wastewater, a benchmark (which has a similar behaviour) and a blank (for the control of the activity of the activated sludge) are monitored. If the organic pollutants from the wastewater are susceptible to be removed through an abiotic process, mainly air stripping, a control installation containing synthetic medium, wastewater to be treated and a toxic substance for the inhibition of the bacterial activity is prepared for abiotic removal. The samples are kept under continuous stirring and aeration on the entire testing period.

The blank control is free of the test substance and consisted of a mixture containing the non-volatile and water soluble test substance, mineral nutrients and a relatively large amount of activated sludge in aqueous medium which is agitated and aerated at $20-25^{\circ} \mathrm{C}$ in the dark or in diffuse light, for up to 28 days. 
Chemical oxygen demand (COD) is analysed at the beginning and at the end of the test and at three regular time intervals. The treatability of the tested wastewater corresponds to the decrease of COD and is expressed as percentage of COD removal.

The degree of maximum degradation is defined as the value from which no essential change of the level of degradation is observed during the test. The test is considered completed when the degradation degree is constant and reaches values higher than $80 \%$ earlier than 28 days.

\section{Results and discussions}

In order to evaluate the biological treatability of wastewaters by means of the Symons criterion, several sampling campaigns ( 7 campaigns) were conducted and the results of the quality indicators are shown in table 1.

Starting from the analysis of the data shown in the following diagram (fig. 1), one may observe that the organic pollutants from the effluents resulting from the paper mill are in a great measure biodegradable and the average of $\mathrm{BOD}_{5} / \mathrm{COD}$ ratio ranges between $1 / 2$ and $1 / 3$. This leads to the increase of the biological treatability of the wastewater mixture and facilitates the secondary treatment process within the municipal wastewater treatment plant.

The results allow establishing the direction of the increase of the biological treatability of the wastewater as follows:

$\stackrel{\text { IWTP }}{\longrightarrow}$

biological treatability according to the $B O D_{5} / C O D$ ratio

In order to determine the biological treatability of the wastewaters using the Zahn-Wellens method, a series of three tests was conducted and the variation of the COD was monitored daily during the experiments. The benchmark substance used in parallel with the tested wastewaters was aniline.

The results allowed the computation of the removal percentage for organic matter from wastewaters and the graphical representation of the degradation curves specific to each sample is depicted (figs. 2-4).

For determining the degree of maximum degradation, the values of COD at the beginning and at the end of the Zahn-Wellens test were taken into consideration (table 2) and the resulting values led to the characterisation of the wastewaters as follows:

-the effluent from the paper mill (EPM) is biologically treatable and the degree of maximum degradation is higher than $80 \%$;

-the influent of the municipal wastewater treatment plant that does not contain the effluent from the paper mill (IWTP) is considered to be biologically treatable as its degree of maximum degradation is close to the threshold of $80 \%$;

-the mixture A consisting of paper mill effluent (EPM) and sewage wastewater (IWTP) is also considered biologically treatable as the degree of maximum degradation is around $80 \%$, however it has a few per cent over EPM.

According to the results of the experimental study, in order to compare the ability of the organic matter to be degraded, the three types of wastewater may be organised as follows:

$$
\underset{\text { biological treatability according to the Zahn-Wellens method }}{\stackrel{\text { Mixture }}{\longrightarrow}}
$$

As one may notice, the information regarding the biological treatability of wastewaters obtained using the indirect method that is the Symons criterion is rigorously

Table 1

\begin{tabular}{|c|c|c|c|}
\hline Type of wastewater & $\underset{\left(\mathrm{mg} \mathrm{O} \mathrm{O}_{2} / \mathrm{L}\right)}{\mathrm{COD}}$ & $\underset{\left(\mathrm{mg} \mathrm{O}_{2} / \mathrm{L}\right)}{\mathrm{BOD}_{5}}$ & $\begin{array}{c}\mathrm{BOD}_{5} / \mathrm{COD} \text { ratio } \\
\left(\frac{\text { minimum } \ldots \text { maximum }}{\text { average }}\right)\end{array}$ \\
\hline EPM & $\frac{1649 \ldots 2790}{1957}$ & $\frac{417 \ldots 1752}{1002}$ & $\frac{0.23 \ldots 0.67}{0.51}$ \\
\hline IWTP & $\frac{172 \ldots 805}{323}$ & $\frac{22 \ldots 225}{99}$ & $\frac{0.13 \ldots 0.57}{0.31}$ \\
\hline Mixture A & $\frac{248 \ldots 345}{306}$ & $\frac{34 \ldots 159}{101}$ & $\frac{0.14 \ldots 0.54}{0.33}$ \\
\hline
\end{tabular}

THE BOD ${ }_{5} /$ COD RATIO REGARDING THE BIOLOGICAL TREATABILITY OF THE WASTEWATER

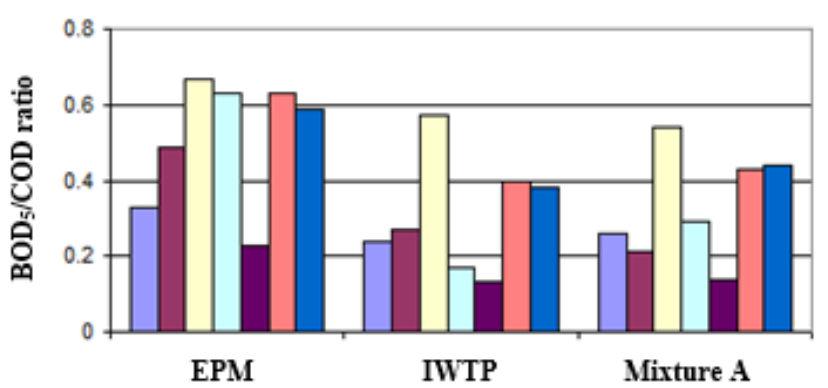

Fig. 1. The variation of the BOD/COD ratio for the analysed types of wastewater for all 7 sampling campaigns and each type of wastewater analyzed 

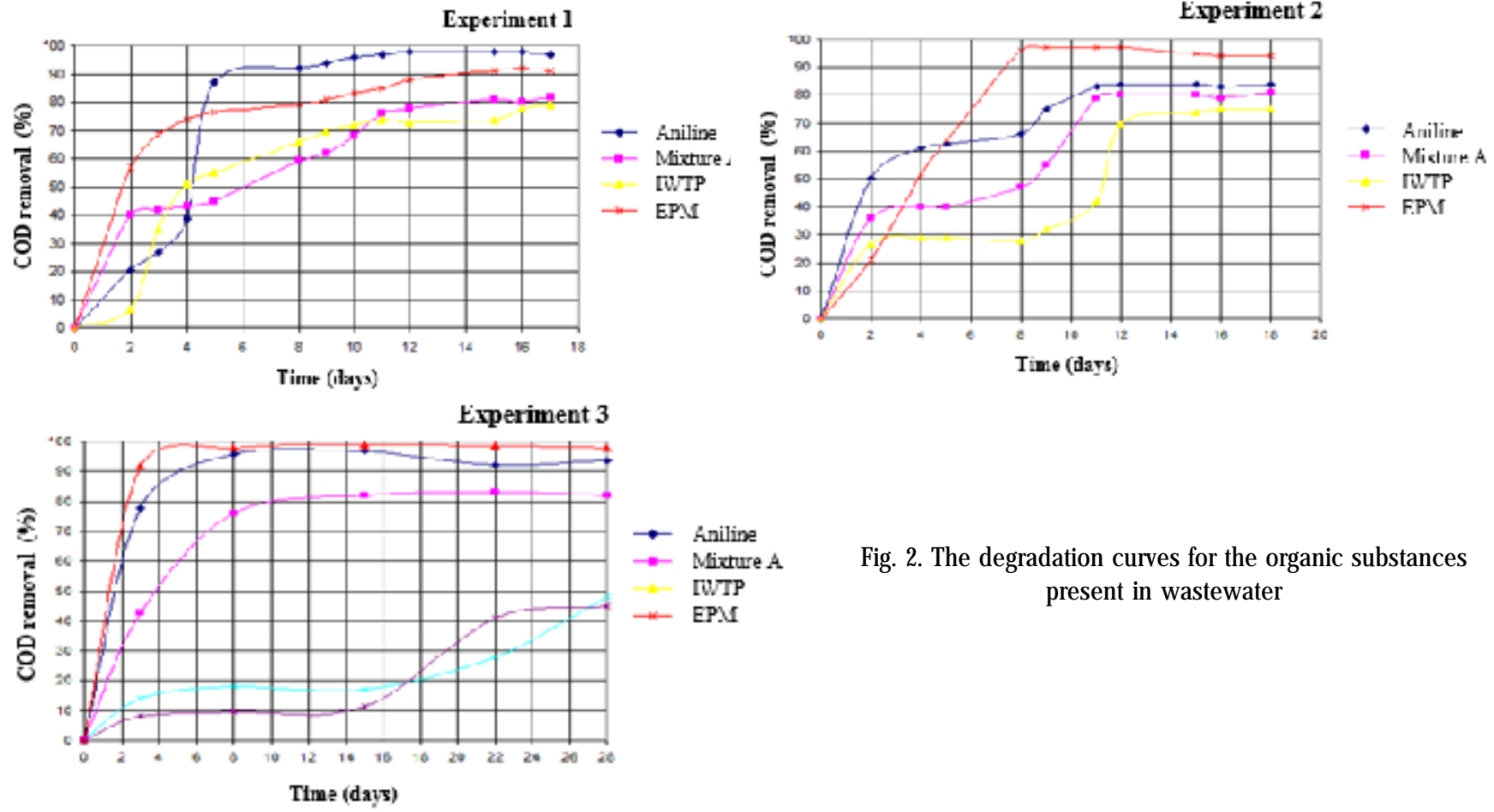

Fig. 2. The degradation curves for the organic substances present in wastewater

\begin{tabular}{|c|c|c|c|c|}
\hline & Type of wastewater & \multicolumn{2}{|c|}{ COD $\left(\mathrm{mg} \mathrm{O}_{2} / \mathrm{L}\right)$} & The degree of max. \\
& Initial & Final & degradation (\%) \\
\hline & EPM & 2450 & 107 & 92 \\
\hline Experiment 1 & IWTP & 670 & 79 & 79 \\
\hline & Mixture A & 330 & 70 & 82 \\
\hline Experiment 2 & EPM & 1652 & 72 & 84 \\
\hline & IWTP & 510 & 53 & 75 \\
\hline Experiment 3 & Mixture A & 245 & 49 & 81 \\
\hline & EPM & 1765 & 68 & 97 \\
\hline
\end{tabular}

Table 2

THE DEGREE OF MAXIMUM DEGRADATION OF THE ORGANIC SUBSTANCES FROM WASTEWATER supported by the specific Zahn-Wellens test, based on the monitoring of the degradation of organic compounds.

\section{Conclusions}

Wastewaters resulting from paper mills are characterised by high contents of organic substances so that their secondary treatment is required, preferably aerobic biological treatment. The selection of the optimum technological solution is affected by the initial concentration of pollutants, by the characteristics of the wastewater (the biological treatability) and by the removal efficiency required so that the effluent meets the limits provided for the discharge in the receptor.

The organic substances present in the wastewaters resulting from paper mills are biodegradable in high proportion, leading to the classification of the effluent as easily treated biologically. These wastewaters may be treated by means of biological processes with good removal efficiencies and the degree of maximum degradation for organic substances determined through the classical ZahnWellens method is over $80 \%$.

Although the organic substances exceed by far the limits provided by the specific legislation regarding their discharge in the municipal sewer, the present study proved that the discharge of wastewaters resulting from paper mills has a positive effect on the biological process employed within the secondary treatment step by enhancing the biological treatability of wastewater mixture.
In the context of the issues regarding the demand of an adequate wastewater treatment in order to ensure the protection of the quality of water resources and of human health, it is essential that the environmental engineer understands the characteristics of process to ensure its effective control. The Symons criterion and the ZahnWellens method enable the evaluation of the biodegradability of the organic pollutants providing the possibility of some estimation regarding the biological treatability of wastewaters and their behaviour in the wastewater treatment processes.

\section{References}

1.NEGULESCU, M., Industrial Wastewater, 1, Technical Publishing House, Bucharest, 1987.

2.DEGREMONT, Water Treatment Handbook, 5th edition, 1, Lavoisier, Paris, 2007.

3.ENE, M.D., JIPA, I., MARIA, G., STOICA-GUZUN, A., STROESCU, M., Rev. Chim. (Bucharest), 62, no.2, 2011, p.227.

4. MARIA, G., Chemical and Biochemical Engineering Quarterly, 18, no.3, 2004, p.195.

5.JUDD, S., STEPHENSON, T., Process Science and Engineering of Water and Wasterwater Treatment, IWA Publishing, London, 2002.

6.ROBESCU, DIANA, STROE, F., PRESURA A., ROBESCU, DAN, Wastewater Treatment Techniques, Technical Publishing House, Bucharest, 2011.

7.MARIA, G., MARIN, A., WYSS, C., MULLER, S., NEWSON, E., Chemical Engineering Science, 51, 1996, p.2891. 
8.MARIA, G., Rev.Chim. (Bucharest), 61, no.2, 2010, p.172.

9. ***SR EN ISO 9888:2004, Water quality standard. Evaluation of the ultimate aerobic biodegradability of organic compounds in the aqueous medium. Static test (Zahn Wellens method), Romanian Association for Standardization (ASRO), Bucharest.

10. MARIA, G., TUDORA, R.M., MARIA, C., Rev.Chim. (Bucharest), 62, no.5, 2011, p.554.

11. MARIA, C., TOCIU, C., MARIA, G., Chemical Papers, 67, no.2, 2013, p.173.
12. NISTREANU, VALERIU, NISTREANU, VIORICA, The Arrangement of Water Resources and Environmental Impact, BREN Publishing House, Bucharest, 1999.

13. *** National Agency for Environmental Protection, National Report on the State of the Environment in Romania for 2016, Bucuresti, 2017. 14. *** SR ISO 6060:1996, Water quality standard. Determination of chemical oxygen demand., Romanian Association for Standardization (ASRO), Bucharest.

15. *** SR EN 1899:2003, Water quality standard. Determination of biochemical oxygen demand., Romanian Association for Standardization (ASRO), Bucharest

$\overline{\text { Manuscript received: } 17.07 .2018}$ 